\title{
Mediadiversiteetti ja mittaamisen politiikka
}

Median monimuotoisuus eli mediadiversiteetti on viestintäpolitiikan perustavoite, jota kukaan tuskin vastustaa. Monipuolisuuden vaatimus liittyy kiistatta demokratiaan ja sananvapauteen, mutta näkemyksiä sen merkityksestä on monia. Julistusten tasolla ongelmaton ihanne kätkee sisälleen myös viestintäpolitiikan keskeiset ristiriidat. Viestintäpolitiikassa ihanne nousee esiin sekä markkinoiden vapautta-

Artikkelissa tarkastellaan mediadiversiteettiä moniselitteisenä ja erilaisiin poliittisiin tarkoituksiin muovailtavissa olevana käsitteenä. Vahvaa positiivista latausta kantavana ihanteena median monipuolisuudesta näyttää tulleen jonkinlainen symbolinen itseisarvo, jolla voi perustella vastakkaisia näkemyksiä viestinnän sääntelystä. Artikkelissa esitetään, että monipuolisuuden ihanteeseen helposti liitettävä arvoneutraalius on harhaanjohtavaa, sillä käsitteiden määrittelyssä, arvioinnissa ja mittaamisessa on aina kyse myös kriteerien valinnasta. Jos mediadiversiteetin ihanne empiiristen määritelmien seurauksena typistyy kuluttajan valinnanvapaudeksi erilaisten ohjelmatyyppien välillä, on sillä epäilemättä myös poliittisia seurauksia. Kriittisestä näkökulmasta tulisikin tunnistaa erilaisten arvioinnin käsitteiden moniselitteisyys ja sopimuksenvaraisuus sekä tarkastella niitä myös poliittisen hallinnan ja normatiivisen vallan välineinä. misen että julkisen palvelun ihanteiden perusteena. Sisällölliseen neutraaliuteen viittaavana ihanteena mediadiversiteetti sopii myös perinteisiä laadun ja yhteisen edun käsitteitä paremmin yhtäältä nykyiseen teknokraattiseen arviointikulttuuriin ja toisaalta myös laajempaan moniarvoisuuden ideologiaan. Voiko monipuolisuutta arvioida objektiivisesti vai onko kyse vain retoriikasta, jota käytetään ja tulkitaan tarkoitushakuisesti ja jolla vältetään laatuun tai median sosiaaliseen vastuuseen liittyvät hankalat kysymykset?

Epämääräisyyttä lisää se, että nykyisessä eurooppalaisessa viestintäpoliittisessa keskustelussa monipuolisuus on yhtäältä omaksuttu abstraktiksi periaatteelliseksi ihanteeksi, joka legitimoi poliittisia tavoitteita, ja toisaalta mitattavaksi ja objektiivisesti arvioitavaksi tavoitteeksi. Onkin syytä tarkastella kriteereitä, joilla näitä ihanteita ylipäänsä voi arvioida, ja pohtia kriittisesti erilaisten määritelmien ja ihanteiden perusteita, ristiriitoja ja poliittisia seurauksia. Tarkastelen artikkelissa keskustelua mediadiversiteetistä kiinnittäen huomiota erityisesti käsitteen empiiristen määritelmien sisältämiin poliittisiin jännitteisiin. Väitän, että ongelmallista näissä on erityisesti keskittyminen kuluttajien valinnanvaihtoehtojen lisäämiseen ilman pluralistisen julkisuuden toteutumisedellytysten syvällisempää pohtimista. Mikä tahansa määritelmä tai empiirinen mittari kuitenkin sisältää valinnan siitä, mikä koetaan tärkeäksi ja millä kriteereillä mediaa arvioidaan. Ylipäänsä poliittisten tavoitteiden käsitteellistäminen ja määrittely ohjaavat aina kysymyksenasetteluja ja vastausvaihtoehtoja, jolloin käsitteitä ja empiirisiä työkaluja on syytä tarkastella myös poliittisen hallinnan välineinä, ei vain objektiivisina mittausvälineinä. Ihanteena, joka kantaa vahvaa positiivista 
latausta, pluralistinen mediajulkisuus on ehkä syytäkin nähdä ennen kaikkea avoimena ihanteena, jonka määrittelystä käydään poliittista kamppailua, ja jonka objektiivisiin määrittely-yrityksiin on syytä suhtautua kriittisesti.

Moniselitteisyyttä korostaa osaltaan myös se, että pluralismia, diversiteettiä, monipuolisuutta ja monimuotoisuutta käytetään usein synonyymeinä ilman selkeitä määrittelyjä1. Palaan vielä käsitteiden eri ulottuvuuksiin, mutta artikkelin tavoite ei kuitenkaan ole esittää niille mitään uusia systemaattisia määritelmiä. Sen sijaan tarkoitus on avata näkökulmia ylipäänsä määritelmien valtaan, ja siihen miten normatiivisesti latautuneet käsitteet ovat muovailtavissa erilaisiin poliittisiin tarkoituksiin. Sovellan artikkelin loppupuolella löyhästi poliittisen hallinnan (gouvernementalité, governmentality) näkökulmaa, joka johtaa kysymyksiin nimenomaan siitä, miten käsitteillä ja tiedon tuottamisen tavoilla oikeutetaan ja legitimoidaan tiettyjä poliittisia tavoitteita ja käytäntöjä (Foucault 1991; Rose \& Miller 1992; Dean 1999; Rose 1999; Kantola 2002). Erityisesti käsitteiden empiiriset objektifikaatiot nousevat tällöin esiin välineinä, joilla luodaan ja ohjataan ilmiöiden poliittista hallintaa. Pohdin artikkelissa ensin erilaisten monipuolisuuden määritelmien ja käyttötapojen normatiivisia taustaoletuksia ja niiden suhdetta viestintäpolitiikan tavoitteenasetteluun. Sen jälkeen kysymykseksi nousee, onko median monipuolisuuden empiirinen mittaaminen ylipäänsä mielekästä ja minkälaisia jännitteitä erilaisiin empiirisiin määritelmiin sisältyy. Perustan artikkelin tulkintaan viimeaikaisesta, lähinnä eurooppalaisesta empiirisestä diversiteettitutkimuksesta ja sen ympärillä käydystä käsitteellisestä keskustelusta. Lopussa käytän esimerkkinä myös Liikenne- ja viestintäministeriön vuosittaista selvitystä suomalaisen tv-tarjonnan monipuolisuudesta.

\section{Viestintäpolitiikka kamppailuna kriteereistä}

Ajatus, jonka mukaan vapaa kansalaiskeskustelu ja mielipiteenmuodostus edellyttävät joukkoviestinnän sisällöllistä monipuolisuutta, on yksi nykyisen sananvapausajattelun kulmakivistä (esim. Nordenstreng 1996). Kansalaisten tarvitseman monipuolisen informaation saatavuus voidaan hahmottaa keskeiseksi sananvapauden toteutumisen edellytykseksi, joka myös velvoittaa julkista valtaa toimenpiteisiin. Vaikka kansalaisten oikeuksien varaan perustuva sananvapausajattelu perimmiltään antaa perusteet myös joukkoviestinnän julkiselle sääntelylle ja julkisen palvelun tavoitteille, on vapausoikeuksien ja monipuolisuuden kaltaisten positiivisten tavoitteiden välillä toisaalta kuitenkin olemassa aina myös jännite (esim. Van Loon 2000). 
Ajatus pelkästään lähettäjän oikeuksia laajemmasta sananvapauden tulkinnas. ta on kuitenkin yleisesti hyväksytty myös poliittisessa keskustelussa, vaikkakin sen tulkinnat vaihtelevat pelkän kuluttajan valinnanvapauden ja laajempien viestinnän oikeuksien välillä. Varsinkin Euroopan neuvoston ja EU:ssa erityisesti Euroopan parlamentin mediaa koskevat julkilausumat ovat viime vuosina kiertyneet vahvasti mediapluralismin ja mediadiversiteetin käsitteiden ympärille. Kansainvälisesti myös Unescon valmistelema kulttuurista monimuotoisuutta koskeva yleissopimus ja sen ympärillä käyty keskustelu viittaavat vahvasti mediadiversiteettiin osana kansalaisten kulttuurisia oikeuksia. Lähes kaikissa näissä myös säännönmukaisesti vahvistetaan julkisen palvelun televisiotoiminnan tarpeellisuus sen turvaamiseksi Tämä erityisasema on v. 1997 vahvistettu Amsterdamin sopimuksen pöytäkirjan kautta myös EU:n perussopimuksiin. Suomessa viestinnän monimuotoisuuden yhteys sananvapauteen on tuotu selkeästi esiin muun muassa perustuslain sananva.paussäännöksen perusteluissa (He 309/1993), laissa Yleisradio Oy:stä (1993) sekä konkreettisimmin televisio- ja radiotoiminnasta annetussa laissa (1998), jonka mukaan toimilupapolitiikassa tulee pyrkiä "sananvapauden edistämiseen sekä turvaa.maan ohjelmistotarjonnan monipuolisuus sekä yleisön erityisryhmien tarpeet".

Lain kirjaimeen tukeutuen ja muiden maiden esimerkkiä seuraten Liikenne- ja viestintäministeriö on myös teettänyt vuosittain selvityksen televisiotarjonnan monipuolisuuden toteutumisesta (Aslama \& Wallenius 2004), mikä osoittaa uudenlaista sitoutumista mediadiversiteetin käsitteeseen myös empiirisessä ja aiempaa konk. reettisemmassa merkityksessä. Monipuolisuus katsotaan tällöin konkreettisesti mittavaksi viestintäpolitiikan tavoitteeksi ja arvioinnin perusteeksi eikä vain yhdeksi sa.nanvapauden abstraktiksi käsitteelliseksi ulottuvuudeksi. Ainakin julkisen palvelun ohjelmiston osalta tämän taustalla voi nähdä kehityksen, jossa julkiset instituutiot kaikilla aloilla joutuvat entistä enemmän perustelemaan tarpeellisuuttaan ja tehokkuuttaan selkeillä tavoitteilla ja niiden toteutumista seuraavilla arviointimittareilla. Toisaalta myös EU:n kilpailupoliittiset näkökulmat ovat pakottaneet kehittämään selkeitä kriteerejä rajaamaan julkisen sääntelyn alaa poikkeuksena vapaan kilpailun periaatteista (Harrison \& Woods 2001, 499; Syvertsen 2003, 167-168).

Monipuolisuus näyttäytyy yleisemminkin neutraalimmalta ja vähemmän arvosidonnaiselta ihanteelta yhteiskunnassa, jossa yhteisen hyvän tai laadun kaltaiset essentialistiset perusteet ovat menettäneet vetovoimaansa. Etenkin empiirisenä käsitteenä se viittaa jonkinlaiseen sisällölliseen neutraaliuteen, jolla pystyttäisiin karistamaan viimeisetkin paternalismin ja holhousmentaliteetin rippeet viestintä.politiikasta. Tämä ei kuitenkaan ole ongelmatonta, sillä myös monipuolisuuden tulkinta on poliittinen ja normatiivinen kysymys, jota ei voida hahmottaa yksise.litteisesti pelkkiin tosiasioihin tukeutuen. Katson tässä, että mediadiversiteetin käsitteen määrittely-yritykset ovat osa median toimintaperiaatteiden julkista mää.rittelykamppailua eli kamppailua arviointikriteereistä, käsitteiden määrittelyistä ja kysymyksenasetteluista. Käsitteen sitominen tiettyyn empiiriseen määritelmään tai indeksiin sen sijaan, että se ymmärrettäisiin jatkuvasti uudelleen määriteltä.väksi ihanteeksi, peittää kuitenkin tämän ulottuvuuden näkyvistä. Kuten Juhani Kortteinen $(1996,46)$ on sananvapausajatteluun viitaten todennut, objektiivisen kielenkäytön vaarana on, että "niin oikeudellisilla sananvapauskäsitteillä kuin journalistien eettisillä säännöillä operoivat harhautuvat uskomaan olevansa teke-misissä vain tosiasiaväittämien eikä arvojen kanssa". Poliittiset ratkaisut joudutaan kuitenkin aina perustamaan viime kädessä arvoihin ja erilaisiin normatiivisiin käsi.tyksiin median roolista yhteiskunnassa.

Mediadiversiteetin käsite juontaa juurensa laajasti ottaen median suoritusta arvioivaan tutkimusperinteeseen, jossa arvoulottuvuudet ja median yhteiskunnal-. 
lisesta roolista käytävät kiistat ovat aina perusongelmana (esim. McQuail 1992). Poliittisena periaatteena joukkoviestinnän monipuolisuus saa kuitenkin sisältönsä aina poliittisen tulkinnan kautta, jolloin myös politiikan analysoinnin kiinnostus kohdistuu erilaisten poliittisten käsitteiden ja instrumenttien kantamiin sosiaalisiin merkityksiin ja arvolatauksiin. Usein todetaankin, että poliittinen ja ideologinen kamppailu merkitsee ennen kaikkea kamppailua käsitteistä, jotka yleisesti koetaan epäpoliittisiksi tai poliittiset rajat ylittäviksi (esim. Hall 1992). Garnham (2000, 165166) väittääkin, että sananvapauden ja median monipuolisuuden kaltaiset moraaliset arvot on erityisen helppo mobilisoida erilaisten intressien palvelukseen, koska niiden lähes mytologinen ja itseisarvoinen status estää niiden perusteiden ja taustaoletusten kriittisen tarkastelun. Mitkä tahansa niiden nimissä esitetyt vaatimukset kuitenkin perustuvat tiettyihin normatiivisiin käsityksiin yksilöstä, yhteiskunnasta ja julkisuudesta. Tässä mielessä tutkimuksellisissa valinnoissa ei siis ole kyse vain keinoja ja menetelmiä koskevista erimielisyyksistä, vaan erilaisista tavoista tulkita ja artikuloida monipuolisen julkisuuden ihanne yhteiskunnallisena tavoitteena.

\section{Pluralismi perusarvona}

Mediadiversiteetin korostamisen taustalla onkin luontevaa nähdä myös laajempia pluralistisia arvoja. Monella tavalla pluralismi on jo sinällään liberaaliin demokratiakäsitykseen ja sananvapausajatteluun kuuluva itseisarvo, eikä vetoaminen monipuolisuuteen ja valinnanvapauteen arkipuheessa yleensä vaadi juuri perusteluja. Kysymyksiä pluralismista voidaan kuitenkin lähestyä myös filosofisemmasta näkökulmasta. Moninaisuuden, suvaitsevaisuuden ja yksilöllisyyden edistäminen on ollut aina yksi liberalistisen yhteiskuntafilosofian perusteemoista. Asettamalla nämä arvot vastakkain valtiokeskeisen yhdenmukaisuuden ja kollektivismin kanssa liberalismi esittää pluralistisen kilpailun ja mielipiteiden moninaisuuden kaikenlaisen kehityksen edellytyksenä - koskien yhtälailla sekä taloudellista kilpailua että poliittista keskustelua (Bobbio 1990, 21-24). Toisaalta pluralismin korostaminen näyttäytyy myös vastakohtana ja pidäkkeenä väitteille massakulttuurista ja mediasta sosiaalisen kontrollin muotona. Esimerkiksi liberalismin kuuluisin yksilön- ja ilmaisunvapauden puolustus, J.S. Millin (1982) essee Vapaudesta, perustuu pitkälti moniarvoisuuden puolustamiseen keinona vastustaa enemmistön sosiaalista tyranniaa. Millin mukaan ilmaisunvapauden perimmäinen tarkoitus on nimenomaan erilaisten mielipiteiden julkinen esiintuominen, jotta erilaisia käsityksiä totuudesta voidaan vertailla ja niiden rationaalisia perusteita arvioida.

Toisaalta liberalismin klassisten periaatteiden lisäksi pluralismin korostamisessa on piirre, joka liittyy essentialististen demokratia- ja sananvapausperiaatteiden horjumiseen. Nykyisissä erilaisuutta ja moniarvoisuutta korostavissa demokratiateorioissa arvopluralismin ja monikulttuurisuuden katsotaan yhä useammin kyseenalaistavan modernin politiikan universalistisia tavoitteita (Kymlicka \& Norman 2000; Mouffe 2000). John Keane (1992) ehdottaakin, että demokratian ja sananvapauden kaltaiset arvot olisi perustavanlaatuisen tai itseisarvoisen periaatteen sijasta ymmärrettävä nykyään ennen kaikkea filosofisen ja poliittisen moniarvoisuuden väistämättömäksi edellytykseksi ja toisaalta käytännön seuraukseksi. Keanen mukaan tämä asettaa myös mediajärjestelmän demokratisoimisen tavoitteiksi ennen kaikkea pluralistisen, sekä markkinoista että valtiosta riippumattomaan kansalaisyhteiskuntaan kytkeytyvän mediajärjestelmän.

Eikö pluralismi tällöin saa itse aseman uutena perustavana ja itseisarvoisena periaatteena? Entä onko kaikki moninaisuus ja vaihtelevuus aina hyvästä vai muuttuuko se jossain vaiheessa hajaannukseksi? Tarkoittaako moniarvoisuus, että kaikki 
on samanarvoista? Lopulta kuitenkin huomioon otettavia näkökulmia on aina rajallinen määrä, jolloin kysymykseksi nousee se, millä kriteereillä niille asetetaan rajat? Toisaalta, samaan aikaan kun puhutaan median monipuolisuudesta ja pluralistisen julkisuuden ihanteesta, sekä poliitikot että tutkijat ovat esittäneet huolta julkisuuden fragmentoitumisesta, liiasta yksilöllistymisestä ja yhteisten julkisuusareenoiden katoamisesta (esim. Gibbons 2000; Sunstein 2003). Näihin ihanteisiin liittyy siis myös todellisia ongelmia, jotka eivät ratkea vain kuluttajan valinnanvapauteen vetoamalla. Jacoby $(1999,33)$ onkin kriittisesti todennut, että pluralismista ja monikulttuurisuudesta on tullut ideologioiden jälkeisen ajan virallisia myyttejä, yritys täyttää aukko, jonka idealismin ja utopioiden kuihtuminen on jättänyt. Vastustamatta ajatusta pluralismista yleisenä arvona voikin kritisoida sitä, että siitä on tullut iskulause, jolla voi perustella mitä vain ilman muuta merkitystä tai sisältöä (Mouffe 1993, 7-8). Toisaalta juuri käsitteen epämääräisyys antaa sille sen ideologisen liikkumavaran, jonka ansiosta sen nimissä voidaan ajaa täysin vastakkaisia poliittisia päämääriä (McLennan 1995, 7).

Tätä taustaa vasten pluralistisiin arvoihin perustuvien konkreettisten viestintäpoliittisten tavoitteiden moniselitteisyys ei olekaan yllättävää. Jonkinlaisena työmääritelmänä mediadiversiteetin käsitteellä voidaan tarkoittaa mediasisältöjen heterogeenisyyttä millä tahansa merkittäväksi katsotulla ulottuvuudella. Keskeistä siinä onkin se, että jokainen määritelmä nostaa esiin jonkin aspektin muiden kustannuksella. Median monimuotoisuutta ei voi mitata absoluuttisesti, vaan aina suhteessa joihinkin kriteereihin ja määritelmiin, jotka katsotaan muita oleellisimmiksi. Mittareista ja operationalisoinnin tavoista muodostuu tällöin helposti ilmiön ymmärtämistä määrittäviä tekijöitä sen sijaan, että ne olisivat vain välineitä. Jan Van Cuilenburg (1998) on todennut, että kaikki monimuotoisuuden määritelmät saavat merkityksensä vain suhteessa yhteiskunnassa vallitsevaan poliittiseen ja kulttuuriseen todellisuuteen. Keskeiseksi kysymykseksi nousee siis tämän suhteen käsitteellistäminen. Vaikka viestinnän tutkimuksessa onkin käyty paljon keskustelua mediadiversiteetin käsitteen erilaisista aspekteista ja mittaamisen menetelmistä sekä tunnustettu käsitteen monitulkintaisuus, eri määritelmiin liittyviä normatiivisia ongelmia ja niiden limittymistä empiirisiin välineisiin on tässä perinteessä pohdittu vähemmän. Tässä artikkelissa en ole kiinnostunut käsitteen uudenlaisesta operaationalisoinnista tai mittaamisen metodologiasta. Sen sijaan on syytä kysyä kriittisesti, minkä takia ja missä merkityksessä mediadiversiteetti onkaan arvokas tavoite, miten siihen tulisi tutkimuksellisesti suhtautua, ja mitä seurauksia sen erilaisilla poliittisilla käyttötavoilla sekä retorisilla ja empiirisillä määritelmillä on.

\section{Mediadiversiteetin poliittinen käsitehistoria}

Median monimuotoisuudesta näyttää siis nykyään tulleen jonkinlainen symbolinen itseisarvo, jolla voidaan perustella vastakkaisia näkemyksiä viestinnän sääntelystä. Sekä kuluttajan valinnanvapauteen perustuva markkinaliberalismi että julkisen palvelun ihanne vetoavat samaan periaatteeseen, mutta määrittelevät itse käsitteen ja erityisesti keinot sen edistämiseksi eri tavoin.

Liberalistisessa ajattelussa moniarvoisuus ja valinnanvapaus yhdistyvät tavallisesti julkisen sääntelyn ja paternalismin vastakohdaksi, mikä heijastuu myös mediahistorian liberalistisessa kertomuksessa siirtymänä julkisen sääntelyn ja suunnittelun paradigmasta kohti markkinoita ja kuluttajan valinnanvapautta (McGuigan 1996, 53; Curran 2002, 22-23). Uusliberalistisessa valinnanvapautta korostavassa yhteiskuntapoliittisessa ilmapiirissä poliittinen suunnittelu saa helposti paternalistisen leiman, kun taas kuluttajan lisääntyvä valinnanvapaus on helppo esittää 
vapautumisena holhoavasta paternalismista. Samalla eksplisiittiset viittaukset moraalisiin tai normatiivisiin perusteisiin ovat saaneet politiikassakin antaa tilaa markkinaorientoituneelle ajattelulle, joka usein ymmärretään aiempaa pragmaattisemmaksi ja neutraalimmaksi.

Van Cuilenburgin ja McQuailin (2003) mukaan kysymyksiin median demokraattisista tehtävistä ja vastuusta perustuva sosiopoliittinen viestintäpolitiikan paradigma on Euroopassa pitkälti korvautunut taloudellisilla ja teknisillä kysymyksillä, jolloin myös yleiseen etuun yhdistettävät tavoitteet ovat painottuneet yhä enemmän taloudellisiin ja konsumeristisiin arvoihin. Toisin kuin ideologioiden oikeuttamassa politiikassa, valintojen oikeutusta etsitään tosiasioista ja välttämättömyyksistä ja poliittiset kysymykset tulkitaan ensisijaisesti teknisiksi kysymyksiksi, jotka vaativat puolueetonta asiantuntijatietoa. Tässä teknokraattisessa asiantuntijadiskurssissa normatiiviset käsitykset yleisestä edusta on yhä vaikeampi sovittaa hallinnon tarvitsemaan empiiriseen ja määrälliseen muotoon (esim. Raboy ym. 2003). Luonteeltaan neutraaliuteen ja objektiivisuuteen viittaavana diversiteettitutkimuksen voikin hyvin ymmärtää tämän kehityksen valossa.

Viestintäpoliittisena tavoitteena sekä sananvapauden ja vapaan mielipiteenmuodostuksen edellytyksenä median monipuolisuus on ollut Suomessa kuitenkin esillä ainakin 1970-luvulta lähtien (Nordenstreng 1974). Aiemmin keskeisenä ongelmana ympäri Eurooppaa nähtiin sanomalehdistön omistuksen keskittyminen, minkä seurauksena luotiin muun muassa lehdistötukijärjestelmiä. Erityisesti 80-luvulta lähtien viestintäpoliittista keskustelua ovat kuitenkin hallinneet sähköisen viestinnän sääntelyn vapautuminen, yleisradiotoiminnan ehdot ja uuden viestintäteknologian mahdollisuudet. Julkisen palvelun kannalta onkin huomautettu, että useissa Euroopan maissa varsinaiset ideologiset ja normatiiviset perusteet sen toiminnalle yleistyivät vasta, kun sen alkuperäiset teknologiset ja pragmaattiset perusteet asetettiin kyseenalaiseksi kilpailun myötä (Collins 1998, 51-57; Hellman 1999a, 58).

Yleisesti hyväksytyille legitimaatioperiaatteille on siis ollut kasvavaa tarvetta, ja näitä onkin muotoiltu viimeisten parinkymmenen vuoden aikana sekä poliittisissa julistuksissa että tutkimuskirjallisuudessa. Julkisen palvelun yhtiöiden kannalta monipuolisuuden korostamista voikin tarkastella myös strategisesta näkökulmasta. Periaatteiden ohella myös julkisen palvelun yhtiöiltä on vaadittu yhä selkeämmin konkreettisia arviointikriteerejä ja vastuuvelvollisuutta, joilla ne oikeuttavat erityisasemansa ja saamansa julkisen rahoituksen. Koska julkisen palvelun ohjelmatarjonta useimmilla mittareilla on yleensä kaupallisia kilpailijoita monipuolisempaa, monipuolisuuden ihanne ja sen mittarit ovat siinä mielessä olleet niille hyvä väline kamppailussa poliittisesta legitimiteetistä (Hellman 1999b, 115).

Toisaalta monipuolisuuden ihanne on ollut keskeisellä sijalla myös markkinoiden vapauttamisen perusteluissa. Perusteiltaan julkinen palvelun järjestelmä ja markkinadiskurssi tukeutuvat kuitenkin erilaiseen monimuotoisuuden määritelmään. Toinen kilpailuun ja kuluttajan valinnanvapauteen, toinen moniselitteisempään poliittiseen tavoitteeseen eli periaatteelliseen pluralismiin, joka ilmentää tavoitetta palvella tasa-arvoisesti koko yhteiskuntaa, erilaisia poliittisia näkemyksiä ja kulttuurisia arvoja (Harrison \& Woods 2001, 481). Karkeasti mediadiversiteetin tulkinnat jaetaankin yleensä markkinahenkiseen käsitykseen, joka viittaa kuluttajan valinnanvaihtoehtojen kasvattamiseen ja perustelee sääntelyn purkamista, ja poliittis-kulttuuriseen määritelmään, jossa mediasisältöjen moninaisuus, tasapuolisuus ja edustavuus pyritään turvaamaan julkisen sääntelyn kautta. Näistä markkinalähtöinen valinnanvapauteen perustuva ihanne on helposti kvantifioitavissa, kun taas julkisen palvelun perustana toimiva laadullisempaan diskurssiin perustuva poliittisen ja kulttuurisen pluralismin ideaali ei. Ylipäänsä julkisen palvelun taustalla olleita kulttuurisia ja yhteiskunnallisia ihanteita onkin ollut vaikea saattaa mää- 
rälliseen muotoon tai ylipäänsä yksiselitteisesti mitattavaksi ja arvioitavaksi, koska sen julkiseen keskusteluun, sosiaaliseen koheesioon ja poliittiseen osallistumiseen liittyvät tehtävät on nähty uusliberalistista valinnanvapauden ja kulutuskysynnän tyydyttämistä huomattavasti laajempina ja diffuusimpana.

Näiden tavoitteiden sisältö onkin ollut pikemmin teoreettisen ja poliittisen keskustelun kuin empiirisen mittaamisen ulottuvilla. Siinä missä kaupallisessa diskurssissa käsitteellisenä lähtökohtana on taloustieteestä lainattu ajatusten vapaan markkinapaikan metafora, niin julkisen palvelun teoreettisena perusteena on käytetty enemmän jonkinlaista neohabermasilaista yhtenäisjulkisuuden ideaalin tulkintaa ja sen mukaista markkinakriittistä perinnettä. Viime aikojen tutkimukset viittaavat kuitenkin siihen, että kuluttajan valinnanvapauteen perustuva markkinakeskeinen diskurssi on tullut mediapolitiikassa siinä määrin hallitsevaksi, että myös julkisen palvelun instituutioiden on täytynyt sopeutua siihen (Hellman 1999b, 124). Valinnanvapaudesta ja vaihtoehtojen määrän lisäämisestä on tullut itseisarvoja, joilla muun muassa sähköisen viestinnän uudet toimiluvat on poikkeuksetta perusteltu (mt., 120-121). Samalla erilaisia tavoitteita on perusteltu lähinnä taloudellisin perustein, jolloin taloussanasto on yhä enemmän alkanut hallita myös viestintäpoliittista keskustelua (Pauwels 1998; Venturelli 1998; Van Cuilenburg \& McQuail 2003).

Gibbons $(2000,307)$ viittaakin siihen, miten mediadiversiteetin käsite itsessään palvelee implisiittisesti siirtymää julkisen palvelun eetoksesta markkinadiskurssiin. Toisin kuin ongelmallinen laadun käsite, neutraali ja objektiivinen monipuolisuuden ihanne ikään kuin kehystää keskustelun median demokraattisesta roolista tekniseksi kysymykseksi, jossa vastakkain on kaksi erilaista keinoa saavuttaa sama päämäärä (monipuolinen mediatarjonta). Asian esittäminen puhtaasti teknisenä erimielisyytenä keinoista sisältää luontevasti myös ajatuksen, että ennen pitkää teknologian kehityksen ja lisääntyvän kilpailun myötä erilaiset markkinahäiriöt voidaan korjata ja julkisen sääntelyn tarve väistyy.

Tällaista keskustelun kehystämisen ja käsitteiden määrittelyn definitionaalista vallankäyttöä kuvaa myös mediapluralismia koskevan lainsäädännön kohtalo EU:ssa. Euroopan parlamentti on toistuvasti 90-luvun alusta lähtien vaatinut komissiota valmistelemaan lainsäädäntöä median monipuolisuudesta (Kaitatzi-Whitlock 1996; Sarikakis 2004). Yritykset tuoda esiin poliittisen ja kulttuurisen monimuotoisuuden pohjalle perustuvaa aloitetta ovat kuitenkin kilpistyneet komission ja erilaisten intressiryhmien vastustukseen, joka on pitkälti perustunut käsitteiden uudelleen määrittelyyn. Yhtäältä mediapluralismi ja kysymykset median riippumattomudesta ja viestintävälineiden omistuksen keskittymisestä on alistettu yleisen kilpailupolitiikan alle, jolloin median erityissääntelylle ei ole tarvetta (Doyle 1997). Toiseksi, eksplisiittisemmin mediasisällöistä puhuttaessa on suosittu lähestymistapaa, jossa diversiteetti määritellään valinnanmahdollisuudeksi erilaisten ohjelmatyyppien välillä, mistä ei ole pitkä matka siihen, että julkisen palvelun tehtävät määritellään tiettyjen rajattujen ja kaupallisesti kannattamattomien ohjelmatyyppien tarjoamiseksi (Feintuck 1999, 59-61; Harrison \& Woods 2001, 495).

\section{Monipuolisuuden paradoksit}

Tavoite ei ole tässä tuottaa mediadiversiteetille uutta ja oikeaa määritelmää, joten esittelen käsitteestä käydyn keskustelun perusjäsennyksiä vain viitteellisesti. Ensinnäkin keskustelu diversiteetistä voi koskea toisaalta sitä, miten media sisällöllisesti heijastaa ja palvelee erilaisia makuja, mielipiteitä ja ryhmiä yhteiskunnassa, ja toisaalta yleisesti median harjoittaman vallankäytön hajauttamista yhteiskunnassa esimerkiksi omistusrakenteiden sekä taloudellisen ja poliittisen vaikutusvallan tasolla. 
Mediadiversiteetti viittaa siten yhtäältä kansalaisten pääsyyn monipuoliseen informaatioon ja toisaalta yhteiskunnallisten toimijoiden ja ryhmien pääsyyn julkisuuteen. Rakenteellinen monipuolisuus ja sisältöjen monipuolisuus erotetaankin usein toisistaan ja vastaavasti sääntelyn keinot erotetaan usein puhtaasti rakenteellisiin keinoihin (esimerkiksi mediaomistuksen rajoitukset) ja toisaalta suoremmin sisältöihin kohdistuviin keinoihin (ohjelmakiintiöt, julkisen palvelun laatuvaatimukset).

Markkinalähtöisessä, usein taloustieteen termejä hyödyntävässä keskustelussa tietolähteiden monipuolisuuden on kuitenkin viestintäpolitiikassa usein ajateltu kausaalisesti johtavan myös tarjolla olevan sisällön monimuotoisuuteen (Napoli 1999). Välineiden määrän, niiden tarjoaman sisällön monipuolisuuden ja yleisön vastaanottaman monipuolisuuden välinen yhteys ei kuitenkaan ole mitenkään lineaarinen, eivätkä empiiriset tutkimustulokset esimerkiksi mediaomistuksen ja kilpailun vaikutuksesta sisältöihin tunnetusti ole yksiselitteisiä (McQuail 1992; Meier \& Trappel 1998; Van der Wurff 2004; Aslama ym. 2004). Toisaalta tutkimustulosten moniselitteisyys ei ole kovin yllättävää, kun otetaan huomioon, että tapoja määritellä mediasisältöjen monipuolisuus on käytännössä loputtomasti, jolloin kilpailu saattaa hyvinkin lisätä monipuolisuutta vaikkapa erilaisten ohjelmatyyppien välillä, mutta samaan aikaan kaventaa esiin pääsevien poliittisten näkemysten kirjoa tai sulkea mediasta kokonaan pois kaupallisesti herkkiä aiheaiheita.

Olennaisempaa onkin vihdoin tarkastella miten sisällöllinen monipuolisuus määritellään. Abstraktilla tasolla mediadiversiteetin voisi määritellä mediasisältöjen heterogeenisyydeksi millä tahansa merkittäväksi katsotulla ulottuvuudella. Nämä ulottuvuudet voivat olla kulttuurisia, alueellisia, kielellisiä, sosiaalisia tai poliittisia, liittyen yhteiskunnallisten ryhmien julkisuuteen pääsyyn, ohjelmatyyppeihin, funktioihin, aiheisiin, poliittisiin näkemyksiin, yleisöryhmiin tai melkein mihin tahansa muuttujaan. Kysymys on siis karkeasti ottaen median suhteesta erilaisiin olemassa oleviin yhteiskunnallisiin eroihin. Tämän suhteen jäsentämisessä seurataan usein McQuailia (1992, 144-145), jonka mukaan sisältöjen monipuolisuuden voi karkeasti hahmottaa kolmella tavalla. Ensimmäisen mukaan median tulisi heijastaa mahdollisimman tarkasti sosiaalista todellisuutta ja vallitsevia eroja yhteiskunnassa. Toisen, avoimutta korostavan näkökulman mukaan median tulisi neutraalisti antaa erilaisille äänille esteetön pääsy julkisuuteen. Kolmanneksi funktioksi voi nähdä valinnanvaihtoehtojen tarjoamisen yleisöille ja kuluttajille. Kuten myöhemmin tulee esiin, useimmat empiiriset määritelmät perustuvat puhtaasti kolmanteen eli valinnanvapauteen, kun taas poliittisena tavoitteena se viittaa laajemmin yhteiskunnalliseen pluralismiin ja vallitsevan yhteiskunnallisen moniarvoisuuden heijastamiseen.

Yksi teknologisen kehityksen ja median digitalisoinnin ennustetuista seurauksista on siirtyminen perinteisestä broadcast-mallista yksilöllisempään narrowcastmalliin, ja siihen liittyvä julkisen ja yksityisen viestinnän rajan hämärtyminen (Feintuck 1999, 23-24). Tähän liittyen on esitetty huolta yleisöjen fragmentoitumisen seurauksista yhteiskunnallisen koheesion ja yhteisen symbolisten viitekehysten kannalta. Vaikka kanavien moninaisuus johtaisikin sisällön monipuolisuuteen, niin toisaalta fragmentoitumista pidetään usein uhkana kansalaisten mahdollisuuksille saada luotettavaa tietoa asioista (Gibbons 2000, 308-311). Valinnanvaihtoehtojen määrä ei sinällään edistäkään yhteiskunnallista keskustelua tai takaa, että kaikilla on siinä yhtäläinen ääni. Van Cuilenburg $(1998,41)$ puhuukin diversiteettiparadoksista eli siitä, että tarjonnan monipuolistuminen saattaa johtaa yhä kapeampiin kohderyhmiin, joiden kosketus muiden näkemysten edustajiin entisestään vähentyy. Saatavilla olevan informaation määrän lisääntymisen myötä näyttäisivät korostuvan näkemykset, joiden mukaan pelkkä välineiden määrän lisääntyminen ei sinällään ole pluralistisen julkisuuden kannalta kovin merkityksellistä. Sen sijaan 
esimerkiksi julkisen palvelun kohdalla tärkeämmäksi muodostuu erilaisia näkemyksiä integroiva ja yhteisiä kulttuurisia tiloja tarjoava funktio.

Julkisen palvelun tehtävänä onkin sekä tutkimuksissa että poliittisessa keskustelussa usein korostettu olevan yhteisen julkisuuden ja sosiaalisen koheesion ylläpitäminen sekä tietoisuuden ylläpitämien sosiaalisista ja kulttuurisista eroista yhteiskunnassa (Harrison \& Woods 2001, 481). Vähemmistöjen ja marginalisoitujen ryhmien palvelemisen funktiona on silloin mahdollista nähdä niiden integroiminen valtakulttuuriin ja erilaisten osajulkisuuksien sovittaminen yhtenäisjulkisuuteen. Digitalisoinnin, konvergenssin ja ylipäänsä kapasiteetin ja kanavamäärien kasvaessa huomio saattaa hyvinkin keskittyä yhä enemmän tähän yhtenäisyysnäkökulmaan. En aio pohtia tarkemmin sääntelyn keinoihin tai lainsäädäntöön liittyviä kysymyksiä tässä, mutta mitä ilmeisimmin keskustelun fokus on siirtymässä pelkistä toimiluvista ja jakelujärjestelmistä laajempiin kysymyksiin erilaisista median saatavuuden pullonkauloista, sisällöntuotannosta, ohjelma- ja lähetysoikeuksista ja ylipäänsä tiedon omistamisesta. Tämäntyyppisestä problematiikasta kielii jo esimerkiksi huoli kansallisesti tärkeiden urheilutapahtumien oikeuksien säilyttämisestä niin sanotuilla yleiskanavilla. Tosin voidaan kysyä, onko urheilu todella juuri se sosiaalisen yhteenkuuluvuuden lähde, jonka saatavuus täytyy turvata lailla.

\section{Mittaamisen politiikka}

Edellä olen käsitellyt monipuolisuuteen poliittisena tavoitteena liittyviä ongelmia ja ristiriitoja. Viestintäpolitiikassa mediadiversiteetti esiintyy yhä useammin kuitenkin myös empiirisesti mitattavana käsitteenä. Amerikkalaisia esikuvia seuraten myös eurooppalaisessa keskustelussa puhutaan nykyään mediadiversiteetin empiirisestä operationalisoinnista ja mittausmetodeista. Rakenteellisesta monipuolisuudesta eli välineiden ja omistuksen monipuolisuudesta on perinteisesti saatu tietoa suhteellisen helposti laskemalla välineiden määrää, markkinaosuuksia tai omistuksen keskittymistä. Jos kuitenkin ajatellaan mediadiversiteetin viittaavan ensisijaisesti juuri sisällölliseen monipuolisuuteen, muuttuu empiirinen mittaaminen paitsi vaikeammaksi myös poliittisesti aremmaksi aiheeksi. Kaikesta huolimatta myös eurooppalaiseen ja suomalaiseenkin mediatalouden ja -politiikan tutkimukseen on kehittynyt omanlaatuinen empiirisen diversiteettitutkimuksen haara, joka määrällisin metodein pyrkii hahmottamaan mediasisältöjen trendejä ( $\mathrm{mm}$. Hellman 2001; van der Wurff 2004; Aslama ym. 2004).

Myös empiirisessä tutkimuksessa muuttujiksi voidaan tietysti määritellä mitkä vain diversiteetin aspekteista. Yleisimmin mediadiversiteetti määritellään kuitenkin niissä nimenomaan ohjelmatyyppien väliseksi hajonnaksi. Ideaalina olisi siis, että kuluttajilla olisi valittavanaan jollain ominaisuudella eritytettyjä tuotteita. Ohjelmatyypit katsotaan tässä katsojien preferenssien kannalta merkitykselliseksi muuttujaksi, koska (1) sen ajatellaan olevan katsojien kannalta merkityksellinen valintakriteeri ja (2) ohjelmatyyppien monipuolisuus katsotaan poliittisesti ja sääntelyn kannalta merkittäväksi tavoitteeksi ja arviointikriteeriksi (van der Wurff 2004, 216). Käytännössä tärkeimmät syyt lienevät kuitenkin operationalisoinnin ja luokittelun helppous, vertailukelpoisuus ja muut tutkimuskäytäntöihin liittyvät seikat.

Tällaisten määrällisten tutkimusten kritisoiminen suhteessa joihinkin normatiivisiin tai poliittisiin ideaaleihin on ehkä epäreilua, sillä niiden tehtävänä lienee pikemmin informaation tuottaminen julkisen keskustelun pohjaksi kuin suorien poliittisten vastausten tarjoaminen (McQuail 1992, 315). Tilastojen ja mittareiden vajaavaisuus todellisuuden kuvaajina lienee kaikkien tiedossa, eikä tarkoitus tässä 
olekaan lähtökohtaisesti kritisoida näitä selvityksiä, vaan pohtia ongelmia, joita liittyy niiden käyttöön poliittisina hallinnan välineinä. Tarkastelua siis ohjaa kriittinen näkökulma politiikan teknokratisoitumiseen ja sen luomien objektifikaatioiden normatiiviseen valtaan. Tutkimuksen kannalta empiiristen diversiteettitutkimusten suurin ongelma onkin siinä, että ne helposti viittaavat median monipuolisuuteen ja ylipäänsä median arviointiin käsitteellisesti yksiselitteisenä ongelmana, joka voidaan ainakin periaatteessa selvittää puhtaasti teknisin keinoin.

Kyse ei siis ole valehtelevista tilastoista vaan siitä, että erilaiset käsitteelliset paradigmat sisältävät väistämättä taustaoletuksia ja erilaisia oikeuttamisen tapoja, jotka osaltaan ohjaavat erilaisia vaihtoehtoja julkisuuden sääntelyssä. Tässä mielessä erilaisia poliittisen hallinnan tapoja voidaan analysoida tutkimalla, miten käsitteillä ja tiedon tuottamisen tavoilla oikeutetaan ja legitimoidaan tiettyjä poliittisen hallinnan tapoja (vrt. Kantola 2002). Keskeisenä on silloin ajatus, että tarjolla olevat käsitteet, teoriat ja todellisuuden representaatiot muodostavat tietynlaisen poliittisen tulkintakehyksen, joka ohjaa päätöksentekijöiden ajattelua ja rajaa vaihtoehtoja. Nikolas Rosen ja Peter Millerin (1992) mukaan politiikkaa ohjaavat aina tietyt idealisoidut skeemat, poliittiset rationaliteetit, jotka ovat sidoksissa tietoon ja teoriaan eli käsitteellisiin representaatioihin, jotka esittävät todellisuuden hallittavassa muodossa. Tällaiset rationaliteetit ovat moraalisia siinä mielessä, että ne perustuvat idealisoituihin ajattelumalleihin ja artikuloivat periaatteet ja päämäärät, joilla päätökset voidaan oikeuttaa. Toisaalta käsitteiden ja sanastojen kanssa kulkevat käsi kädessä sekä tietyt hallinnan teknologiat eli tavat, joilla todellisuus muunnetaan hallinnan kalkylointeihin sopivaksi että tavat, joilla se saadaan mukautumaan interventioihin.

Ajatus maailman tekemisestä jollain tavalla hallittavaksi poliittisten interventioiden tarpeisiin perustuu Foucault'n (1991) ajatuksiin tiedon ja vallan suhteesta, totuuden diskursiivisesta tuottamisesta ja erilaisista hallinnan teknologioista. Moderneissa yhteiskunnissa hallinnan kohteeksi saatettavat tapahtumat on käännettävä informaatioksi, raporteiksi ja tilastoiksi, jotka itsessään ovat myös tapoja vaikuttaa todellisuuteen ja suunnitella tekniikoita todellisuuden saattamiseksi hallittavaksi arvioimista, analysoimista ja poliittista sääntelyä ajatellen (Rose \& Miller 1992; Rose 1999). Hallinnan näkökulmaa voikin soveltaa diversiteettitutkimuksen kritiikkiin juuri siksi, että se kieltää erilaisten tutkimusten, tilastojen ja selvitysten ja niiden käyttämien käsitteellistämistapojen roolin vain neutraaleina välineinä ja kiinnittää huomiota siihen, miten ne kytkeytyvät laajemmin poliittisiin määrittelykamppailuihin. Toisaalta tästä näkökulmasta diversiteettipuhetta voi tarkastella myös siinä mielessä, miten se hyödyntää erityisesti tieteellistä puhetapaa ja sen objektiivisutta totuuden tuottamisen välineenä.

Toisin sanoen analysoitaessa normatiivisia valintoja nykyisessä viestintäpolitiikassa on syytä analysoida paitsi erilaisten käsitteiden juuria ja historiaa, niin myös niiden käyttöä politiikassa ja niiden operationalisoimista käytännöllisiksi poliittisen hallinnan välineiksi. Kantola (2002) on tutkinut hallinnan näkökulmasta erityisesti hyvinvointivaltiollisen hallinnan regiimin korvautumista uudella uusliberalistisella ja markkinaehtoisella regiimillä, joka sinällään näyttäisi pätevältä selitysmallilta myös viestintäpolitiikan muutosten tulkintaan (vrt. Venturelli 1998; Pauwels 1998; Van Cuilenburg \& McQuail 2003). Tässä suuntaan kriittisen tarkastelun kuitenkin rajatummin mediadiversiteetin käsitteen ja erityisesti sen empiirisen mittaamisen sisältämiin oletuksiin ja valintoihin. Kyse on tässä myös tutkimuksen itsereflektiosta, sillä akateeminen tutkimus yhtäältä tuottaa empiirisiä välineitä, joita sovelletaan politiikan analyyseissa ja suunnittelussa, ja toisaalta luo ja määrittelee käsitteitä, jotka aikanaan liukuvat myös poliittiseen kielenkäyttöön ja joita käytetään poliit- 
tisessa keskustelussa päätösten oikeuttamiseen. Jos suomalaisen televisiotarjonnan monipuolisuutta selvittävä tutkimus väittää kategorisesti arvioivansa "miten suomalainen kanavavalikoima ohjelmistoineen palvelee yleisöä" (Aslama \& Wallenius 2004, 69), on todella syytä tarkastella, minkälaiset käsitteelliset esioletukset yleisön tarpeista näitä tutkimuksia ohjaavat.

\section{Valinnanvapauden harha}

Esitän empiirisen diversiteettitutkimuksen kritiikin tässä kolmelta kantilta. Ensinnäkin valinnanvapauden ihanne ylipäänsä on rajallinen käsitteellis-normatiivisena mallina mediadiversiteetin tarkasteluun. Sen taustalla on oletus kuluttajista, joiden preferenssit jakautuvat erilaisten ohjelmatyyppien kesken, jolloin mediajärjestelmä tyydyttää parhaiten valinnanvapauden tarjoamalla erilaisia ohjelmatyyppejä. Media siis käsitteellistetään ensisijaisesti kulutushyödykkeenä, jolloin poliittisen pluralismin ihanteeseen kuuluvat yhteiskunnallinen edustavuus, avoimuus ja muut arvojen kannalta ongelmalliset aspektit tulevat pitkälti sivuutetuiksi. Toiseksi monipuolisuuden erilaisten aspektien redusoiminen pelkäksi ohjelmatyyppien jakaumaksi ei ole vain tutkimuskäytännöllinen valinta, vaan keskustelun kehystäjänä sillä on myös poliittisia seurauksia. Tällaisen operationalisoinnin seurauksena erityisesti julkisen palvelun ylläpitämät laadulliset ja kokonaisvaltaisemmat ihanteet marginalisoituvat. Kolmanneksi diversiteetin mittaamisen empiirisesti voi kyseenalaistaa myös periaatteellisista syistä. Monipuolisuuden esittäminen mitattavana muuttujana nimittäin suuntaa viestintäpolitiikkaa ylipäänsä pois arvovalinnoista ja julkisesta keskustelusta, välineelliseen ja teknokraattiseen päätöksentekoon. Kaiken kaikkiaan tässä vaiheessa on jo etäännytty hyvin kauas yhtäältä yhteiskuntafilosofisista ihanteista, joihin pluralistiset arvot tukeutuvat, ja joihin poliittisissa julistuksissa viitataan.

Median kriittisen poliittisen taloustieteen edustajien esittämän standardikritiikin mukaan vapaaseen kilpailuun ja kuluttajien valinnanvapauteen perustuvat mallit ovat puutteellisia aina jättäessään huomiotta, että valinnan vaihtoehdot ovat aina markkinoiden omien sääntöjen ennalta rajoittamat (esim. Curran 2002, 230). Kysymys valinnan vaihtoehdoista ei olekaan vain empiirinen kysymys vaan on myös kyse siitä, kuka määrittelee vaihtoehdot. Abstraktimmin voidaan sanoa, että median ja julkisuuden sääntely, olkoon kyse julkisesta sääntelystä, markkinasääntelystä tai itsesäätelystä, palautuu aina tavalla tai toisella valintoihin ja vaihtoehtojen rajoittamiseen joillakin kriteereillä. Valintojen perustana voi olla joko poliittinen päätöksenteko, markkinamekanismi tai asiantuntijavalta, mutta mikään niistä ei ole lähtökohtaisesti tai luontaisesti vapaa tai epävapaa.

Markkinoiden vapauttaminen ei siis automaattisesti lisää yksilön vapautta, vaan yhtälailla myös markkinat luovat yksilöä rajoittavia toimintapakkoja ja sääntöjä. Zygmunt Baumanin (1999) mukaan julkisen vallan tehtävänä onkin läpi modernin yhteiskunnan ollut ylipäänsä turvata kansalaisille valinnan vaihtoehtojen olemassaolo. Julkisen sääntelyn purkamisen voi silloin määritellä tarkoittavan tämän valtion esivalintaroolin siirtymistä markkinoille tai muille poliittisen järjestelmän ulkopuolisille tahoille. Samalla valta määritellä arvot, joiden perusteella valintoja tehdään, siirtyy politiikasta markkinoille. Yleisen kritiikin mukaan markkinoiden valta tässä suhteessa merkitsee erilaisten markkinoiden luomien tarpeiden asettumista valintoja ohjaaviksi periaatteeksi. Baumanin mukaan arvoja, joita kuluttajat opetetaan seuraamaan, ovat viihteellisyys, itsekeskeisyys ja hedonistisuus. Seurauksena jälkimoderni yksilöllistyminen ja valinnanvapauden kasvu ei olekaan lisännyt yksilöllistä vapautta vaan pikemminkin "epävapautta" muuttamalla yksilön poliittisesta kansalaisesta pelkäksi markkinahyödykkeiden kuluttajaksi (mt., 75-78). 
Ajatus, että politiikan tulisi huolehtia siitä, että on olemassa todellisia valinnan vaihtoehtoja on tietysti erityisesti yleisradiotoiminnan perimmäinen peruste. Uusliberalismin neutraalin markkinadiskurssin paradoksi onkin siinä, että sen oma illuusio neutraaliudesta ei salli ajatusta, että julkisesti tuetaan mitään tiettyä kulttuurista ihannetta, mitään arvosidonnaista laadun määritelmää. Kuitenkin jos tavoitteeksi määritellään vain negatiivisen valinnanvapauden turvaaminen yhteisillä pelisäännöillä, saattaa todellisen moniarvoisuuden ihanne jäädä entistä kaukaisemmaksi: "Yksilön vapaiden valintojen tuloksena voi syntyä yhteiskunta, jossa kaikki katsovat samoja tv-kanavia, lukevat samoja lehtiä, äänestävät samoja puolueita ja ajattelevat suurin pirtein samalla tavoin" (Lagerspetz 1996, 59).

Jos jätetään julkisen sääntelyn ja valinnanvapauden filosofinen kritiikki sikseen, voi vallitsevissa diversiteetin määritelmissä nähdä analogian myös markkinointilogiikan ja kohdeyleisöjen pilkkomisen kanssa. Ang (1991) kritisoi tunnetussa tutkimuksessaan television yleisötutkimusta hallinnan teknologiana, joka luo televisioyleisöstä objektiivisesti tutkittavan konstruktion hallinnollisiin tarpeisiin - siis hallinnan kohteen. Diversiteettitutkimuksesta ei ole vaikea löytää tavallaan käänteistä analogiaa tähän. Siinä media kulttuurisena instituutiona redusoidaan pelkästään erilaisia taloustieteellisen hypoteettisesti määriteltyjä tarpeita tyydyttäväksi jakelujärjestelmäksi ja sisällöt ohjelmatyyppeihin tai muihin vastaaviin muuttujiin typistyviksi kulutustuotteiksi.

Paitsi että laskemalla erilaisten ohjelmatyyppien määrää ohjelmistossa ei saada mitään tietoa ääneen pääsevien tahojen ja yhteiskunnallisten näkökulmien monipuolisuudesta, on ohjelmatyyppejä korostava logiikka myös itsessään monella tavalla ongelmallinen. Tämä korostuu erityisesti siinä, että selvityksissä ohjelmatyyppien luokituksessa käytetään pitkälti mediayhtiöiden itsensä kehittämiä ohjelmatyyppien luokitteluja (Aslama \& Wallenius 2004, 18). Van Cuilenburgin (1998) mukaan siis diversiteetti on aina suhteutettava johonkin median ulkopuoliseen yhteiskunnalliseen todellisuuteen, mutta suhteessa mihin monipuolisuutta verrataan, jos lähtökohtana ovat tuotannon määrittelemät olemassa olevat ohjelmakategoriat. Televisioyhtiöt kategorisoivat ensin omat ohjelmansa tiettyihin ohjelmatyyppeihin ja tutkijat omaksuvat ne tutkimuksiinsa, joiden tuloksena todetaan, että ohjelmisto on monipuolista. Tällöin on vaikea välttää vaikutelmaa, että diversiteetti-indekseistä tulee kehäpäätelmiä, jotka oikeuttavat säännöllisesti toteamaan olemassa olevan ohjelmiston monipuolisuuden ja tehtyjen poliittisten valintojen menestyksellisyyden. Toisin sanoen mediadiversiteetin tarkastelu irrotetaan täydellisesti ympäröivästä yhteiskunnasta jonkinlaiseksi omalakiseksi legitimaatiodiskurssiksi.

Erityisesti keskittyminen ohjelmatyyppien luokitteluun on ongelmallinen julkisen palvelun näkökulmasta. Kysymys siitä, voidaanko julkisen palvelun tehtävät määritellä ohjelmatyyppien perusteella, on ollut kauan keskeinen kiistakysymys viestintäpolitiikassa. Käytännöllisten luokitteluongelmien lisäksi perustava ongelma on siinä, että julkinen palvelu on perinteisesti perustunut kulttuuriseen ja sosiaaliseen monipuolisuuteen ja informatiivisuuteen, joka korostaa laadullisia kriteerejä ohjelmatyypeistä riippumatta (Harrison \& Woods 2001, 495). Tämä laadullinen eetos tulee esiin myös Ylen kehitysjohtaja Juhani Wiion (2005) puheenvuorossa, jossa hän perustelee julkisen palvelun tarvetta artikuloida oikeutuksensa uskottavasti kaikissa ohjelmaformaateissa. Wiion mukaan julkisen palvelun on pakko kilpailla samoilla ohjelmaformaateilla kuin kaupallisen television. Kysymys vaan on siitä, "miten julkisen palvelun televisio voi hyötyä tosi-tv-buumista tinkimättä kuitenkaan ohjelmapolitiikkansa perusteista?" (mt., 126). Yleisradion ei siis tule hylkiä mitään ohjelmatyyppejä, mutta sen ohjelmistossa on oltava laadullinen ero kaupalliseen tarjontaan ja sen täytyy kestää erityiset eettisen tarkastelun kriteerit. 
Lisäksi diversiteettitutkimuksissa toistuu usein myös ajatus kanavien välisestä työnjaosta. "Monipuolisuusanalyysi ei siis ainoastaan todenna suomalaisen tv-tarjonnan monipuolisuutta, vaan viittaa myös siihen, että kanavat toteuttavat entistä selvempää työnjakoa" (Aslama \& Wallenius 2004, 8). Puhuttaessa työnjaosta, erikoistumisesta ja yleiskanavien muuttuvasta roolista kohdataan kuitenkin jo aiemmin esiin tulleita kulutuksen kaventumiseen ja fragmentoitumiseen liittyviä ongelmia, jotka selvityksissä sivuutetaan. Työnjakokin nimittäin koskee vain tarjontaa, eikä se takaa, että yleisö omaksuu saman työnjaon. Siitä ei myöskään ole pitkä matka ajatukseen, että julkisen palvelun tehtäväksi työnjaossa jää ainoastaan erityisyleisöjen palveleminen ja kaupallisesti epäkannattavien ohjelmien tarjoaminen.

Pitäisikö monimuotoisuuden empiirisestä mittaamisesta sitten luopua kokonaan? Vaikka empiirisissä tutkimuksissa todetaan käytettyjen käsitteiden moniselitteisyys, määrittelyt implisiittisesti viittaavat kuitenkin objektiivisuuteen eli siihen, että niihin ei liity mitään normatiivista ulottuvuutta. Mikä tahansa mittari kuitenkin itsessään sisältää arviointikriteerien valinnan. Myös diversiteettitutkimus on siis median suorituksen arvioimista tietyllä valitulla normatiivisella kriteerillä. Sen lisäksi, että mediadiversiteetin mikä tahansa operationalisointi on aina kyseenalainen, siihen liittyy aina myös poliittinen ja normatiivinen aspekti. Näiden ongelmien ohella muun muassa Van Cuilenburg (1998) on todennut, että nykyisessä yltäkylläisessä mediaympäristössä diversiteetti mitattavana käsitteenä menettää joka tapauksessa merkityksensä, ja tarjontakeskeisen ajattelun sijasta tulisi keskittyä tasaamaan rakenteellisia epätasa-arvoisuuksia, esimerkiksi tukemalla aktiivisesti vähemmistöryhmien ja marginaalisten toimijoiden resursseja ja toimintakykyä sekä kansalaisten tasa-arvoista pääsyä erilaisiin tietolähteisiin.

\section{Haasteita tutkimukselle}

Olen edellä korostanut mediadiversiteetin käsitteen moniselitteisyyttä ja monitahoisuutta sekä normatiivisena periaatteena että poliittisena tavoitteena. Poliittiset argumentit median monipuolisuudesta ovatkin perusluonteeltaan avoimia ja niiden sisällöllinen määrittely riippuu aina tulkinnasta. Hyvin yleisellä tasolla pluralismi lienee politiikan arvopäämääränä tai orientaationa yleisesti hyväksytty. Ongelmaksi sen määrittely muotoutuu kuitenkin silloin, kun sillä perustellaan käytännön poliittisia valintoja tai kun esitetään empiirisiä määritelmiä, joiden väitetään kuvaavan objektiivisesti ja arvoneutraalisti monipuolisuuden toteutumista. Oma kantani on, että kysymys monipuolisuudesta, kuten myös sananvapauden tai julkisuuden kaltaiset abstraktit normit, joiden pohjalle tavoitteet rakentuvat, on avoin ja sen määritelmät ovat jatkuvasti neuvoteltavissa. Tällaisen perustan tai objektiivisten mittareiden kieltäminen ei kuitenkaan tarkoita relativismin hyväksymistä arvokysymyksissä, vaan kuten esimerkiksi Mouffe (1993, 145) ja Keane (1992) korostavat, se että demokraattisilla instituutioilla, media mukaan lukien, ei ole mitään kiistatonta ja objektiivista perustaa, tekee niiden puolustamisesta entistä tärkeämpää. Kun ymmärretään, että demokraattiset instituutiot eivät ole minkään moraalisen evoluution sen enempää kuin tieteellisen suunnittelunkaan tulosta, tulee selväksi, että demokratisoiminen on prosessi ja kamppailu, jonka suunnasta on jatkuvasti keskusteltava.

Toisaalta myös empiiristen arviointimenetelmien kehittämistä joka tapauksessa jatketaan. Tarve legitimoida poliittisia tavoitteita erilaisilla arviointikriteereillä voidaan kai ottaa nyky-yhteiskunnassa realiteettina, johon on sopeuduttava. Ajatukseen median vastuuvelvollisuudesta ja arvioinnista ei sinällään ole syytä suhtautua kielteisesti, mutta vähintäänkin niitä koskevalta tutkimukselta voi odottaa reflek- 
siivisyyttä. On syytä paitsi kehittää kriteereitä, myös esittää kriittisiä kysymyksiä erilaisia määrittelyjä kohtaan. Mediatutkijat tuskin alistuvat sankoin joukoin kehittelemään teknokraattisiin tarpeisiin laatumittareita, mutta yhteys konkreettisiin poliittisiin kysymyksiin kriittisen sivustaseuraajan roolissa olisi tarpeen. Kuten olen artikkelissa korostanut, kriittisestä näkökulmasta on syytä nostaa esiin ainakin arvioinnin käsitteiden moniselitteisyys ja sopimuksenvaraisuus sekä tuoda esiin niiden kantamien poliittisten rationaliteettien taustoja ja vaikutuksia.

Etäisyys mediakulttuuria laadullisesti tarkastelevan kulttuurintutkimuksen ja entistä teknokraattisempaan suuntaan kulkevan poliittisen keskustelun välillä näyttäisi kuitenkin olevan ylittämättömän leveä. Jos hallinnollisia viestintäpolitiikan tutkimuksia voi kritisoida yksipuolisuudesta, niin akateemisen viestinnän tutkimuksen kannalta on todettu, että samalla kun joukkoviestinnän kehitys on kulkenut yhä voimakkaammin markkinavoimien sanelemaan suuntaan, viestinnän tutkimuksessa on otettu entisestään etäisyyttä taloudellisiin rakenneselityksiin ja poliittisen taloustieteen näkökulmaan (Ampuja 2002). Sen sijaan kulttuurintutkimus on yleensä kiinnostunut merkitysten rakentumisesta arkielämän kontekstissa ja poliittisen taloustieteen näkökulmaa on siinä kritisoitu taloudellisten rakenteiden ylikorostamisesta. Myös Jostein Gripsrud (1997) kritisoi taannoin yleisöjen tutkimiseen keskittynyttä viestinnän tutkimusta "olohuoneen politiikan" korostamisesta laajemman yhteiskunnallisen kontekstin ja kokonaisvaltaisen sosiologisen lähestymistavan kustannuksella. Hänen mukaansa tämä on johtanut puutteelliseen ymmärrykseen joukkoviestinnän yhteiskunnallisista määreistä ja vähentänyt valmiutta osallistua julkiseen keskusteluun viestinnän sääntelyn normeista. Kulttuurintutkimuksen yleisökäsitys onkin ehkä luontevammin yhteensopiva kuluttajan valinnanvapautta korostavan markkinaliberalismin kuin holhoavan suunnittelumentaliteetin kanssa (McGuigan 1996; Garnham 2000). Jos arvojen ja merkitysten moninaisuuden johdosta julkista intressiä on mahdotonta määritellä, on ehkä helpompi antaa markkinoiden tarjota jokaiselle yksilöllisesti sitä mikä käy kaupaksi. Toisaalta poliittisten kannanottojen välttäminen mediakulttuurin monimutkaisuuteen ja ristiriitaisuuteen vetoamalla voi pelkän mediakulttuurin muutoksen ohella kertoa myös tutkijoiden kyvyttömyydestä.

Median arvioinnin suhteen kiinnostavia avauksia edellä mainitun kuilun ylittämiseksi voisikin etsiä laadullisen yleisötutkimuksen ja viestintäpolitiikan lähestymistapojen välimaastosta. Hieman eri tutkimusperinteitä edustavat Raboy, Proulx ja Dahlgren (2003) ovat lanseeranneet käsitteen sosiaalinen tarve (social demand), joka pyrkii yhdistämään poliittisten vaateiden analyysin yleisöjen itsensä ilmaisemiin medialle asetettuihin odotuksiin pyrkien siten ylittämään pelkästään markkinoiden välittämät kuluttajan preferenssit. Toisaalta empiirisenä käsitteenä se ottaa etäisyyttä myös poliittis-filosofiseen yleisen edun käsitteeseen. Tarkoituksena on siten etsiä uutta perustaa viestintäpolitiikan tavoitteiden ja niiden legitimiteetin tarkasteluun ja samalla kuroa umpeen kvalitatiivisen yleisötutkimuksen ja perinteisen viestintäpoliittisen lähestymistavan välistä kuilua.

Sen perusteella näyttää siis siltä, että poliittisesti relevantti median arvioiminen vaatii eri näkökulmien yhdistämistä. Määrällinen tutkimus sisällöistä täytyy yhdistää sekä taloudellisten ja poliittisten rakenteiden kriittiseen analyysiin että laadullisempaan ymmärrykseen median merkityksestä yleisöille. Toisaalta päämäärät ja keinot on syytä pitää tässäkin keskustelussa erillään, sillä päämäärien asettaminen on poliittinen kysymys, kun taas mittareiden suunnittelu tulisi perustua näihin päämääriin enemmän kuin toisin päin. Lopultakaan mediajärjestelmän suoritukseen, laatuun ja yhteiseen etuun liittyvät kysymykset eivät ole mitattavissa muulla kuin julkisen keskustelun mittarilla; pyrkimykset vetää mutkat suoriksi ja ratkaista arvokysymykset markkinoiden näkymättömän käden tai kaikkivoipien tieteellisten menetelmien avulla lienevät kaikki yhtä huonoja. 


\section{Viite}

1 Englanninkielessä 'media pluralism' esiintyy yleensä poliittisena tavoitteena tai yhteiskunnallisena arvona, kun taas 'media diversity' viittaa selkeämmin empiiriseen suuntaan. Tämäkin jako tosin häilyy ja kummankin termin suomennoksena käytetään usein synonyymisesti käsitteitä median monipuolisuus tai monimuotoisuus. Näidenkin väliltä voi toki löytää merkityseron, mutta itse en tässä ehdota mitään systemaattista erontekoa.

\section{Kirjallisuus}

Ampuja, Marko (2002)

Joukkoviestinnän kaupallistuminen ja mediatutkimuksen haasteet. Tiedotustutkimus 25:4, 3-17.

Ang, len (1991)

Desperately Seeking the Audience. London: Routledge.

Aslama, Minna \& Heikki Hellman \& Tuomo Sauri (2004)

Does Market-Entry Regulation Matter? Gazette: The International Journal for Communication Studies 66:2, 113-132.

Aslama, Minna \& Jaana Wallenius (2004)

Suomalainen televisiotarjonta 2003. Liikenne- ja viestintäministeriön julkaisuja 58/2004. Helsinki.

Bauman, Zygmunt (1999)

In Search of Politics. Cambridge: Polity Press.

Bobbio, Norberto (1990) Liberalism and Democracy. London: Verso.

Collins, Richard (1998)

From Satellite to Single Market: New Communication Technology and European Public Service Television. London: Routledge.

Curran, James (2002)

Media and Power. London: Routledge.

Dean, Mitchell (1999)

Governmentality. Power and Rule in Modern Society. London: Sage.

Doyle, Gillian (1997)

From 'Pluralism' to 'Ownership': Europe's emergent policy on Media Concentrations navigates the doldrums. Journal of Information, Law and Technology 1997:3 <http://elj.warwick.ac.uk/jilt/commsreg/97_ 3 doyl/>

Feintuck, Mike (1999)

Media Regulation, Public Interest and the Law. Edinburgh University Press.

Foucault, Michel (1991)

Governmentality. Teoksessa Graham Burchell, Coling Gordon \& Peter Miller (toim.) The Foucault Effect.

Studies in Governmentality. London: Harvester Wheatsheaf, 87-104.

Garnham, Nicholas (2000)

Emancipation, the Media and Modernity. Oxford University Press.

Gripsrud, Jostein (1997)

Kulttuurintutkimus ja interventio televisiopolitiikkaan. Tiedotustutkimus 20:1, 34-43.

Gibbons, Thomas (2000)

Pluralism, guidance and the new media. Teoksessa Marsden, Christopher (toim.): Regulating the Globa Information Society. London: Routledge, 304-315.

Hall, Stuart (1992)

Kultuurin ja politiikan murroksia. Tampere: Vastapaino.

Harrison, Jackie \& Lorna Woods (2001)

Defining European Public Service Broadcasting. European Journal of Communication 16:4, 477-504

He 309/1993 vp.

Hallituksen esitys Eduskunnalle perustuslakien perusoikeussäännösten muuttamisesta.

Hellman, Heikki (1999a)

From Companions to Competitors. The Changing Broadcasting Markets and Television Programming in Finland. University of Tampere. Acta Universitatis Tamperensis 652.

Hellman, Heikki (1999b)

Legitimations of Television Programme Policies. Patterns of Argumentation and Dicursive Convergencies in a Multichannel Age. Teoksessa Alasuutari, Pertti (toim.) Rethinking the Media Audience. London: Sage.

Hellman, Heikki (2001)

Diversity - An End in Itself? Developing a Multi-measure Methodology of Television Prigramme Variety Studies. European Journal of Communication 16:2, 181-208.

Jacoby, Russell (1999)

The End of Utopia. Politics and Culture in an Age of Apathy. New York: Basic Books.

Kaitatzi-Whitlock, Sophia (1996)

Pluralism and Media Concentration in Europe. Media Policy as Industrial Policy. European Journal of Communication 11:4, 453-483.

Kantola, Anu (2002)

Markkinakuri ja managerivalta. Poliittinen hallinta Suomen 1990-luvun talouskriisissä. Helsinki: Loki-kirjat.

Keane, John (1992) 
Democracy and the Media - Without Foundations. Political Studies XL: Special Issue, 116-127.

Kortteinen, Juhani (1996)

Sananvapaus ihmisoikeutena. Teoksessa Nordenstreng, Kaarle (toim.) Sananvapaus. Helsinki: WSOY, 32-89.

Kymlicka, Will \& Norman, Wayne (eds.) (2000)

Citizenship in Diverse Societies. Oxford University Press.

Lagerspetz, Eerik (1996)

Vapaus, yksilöllisyys ja yhteiskunta. Teoksessa Antti Hautamäki, Eerik Lagerspetz, Juha Sihvola, Juha Siltala

\& Jarmo Tarkki: Yksilö modernin murroksessa. Tampere: Gaudeamus, 45-62.

Laki televisio- ja radiotoiminnasta. 744/1998.

Laki Yleisradio Oy:stä. 1380/1993.

McLennan, Gregor (1995)

Pluralism. Buckingham: Open University Press.

McQuail, Denis (1992)

Media Performance. Mass Communication and the Public Interest. London: Sage.

McGuigan, Jim (1996)

Culture and the Public Sphere. London: Routledge.

Meier, Werner E. \& Trappel, Joseph (1998)

Media Concentration and the Public Interest. Teoksessa McQuail, Denis \& Siune, Karen (toim.) Media Policy.

Convergence, Concentration and Commerce. London: Sage, 38-59.

Mill, J.S. (1981)

Vapaudesta. Helsinki: Librum.

Mouffe, Chantal (1993)

The Return of the Political. London: Verso.

Mouffe, Chantal (2000)

The Democratic Paradox. London: Verso.

Nordenstreng, Kaarle (1974)

Tajuntateollisuus: Viestintäpolitiikan näköaloja. Helsinki: Weilin + Göös.

Nordenstreng, Kaarle (1996)

Katsomosta Areenalle. Teoksessa Nordenstreng, Kaarle (toim.) Sananvapaus. Helsinki: WSOY, 272-288.

Napoli, Philip M. (1999)

Deconstructing the Diversity Principle. Journal of Communication 49:4, 7-34.

Pauwels, Caroline (1998)

From Citizenship to Consumer Sovereignty: The Paradigm Shift in the European Audiovisual Policy.

Teoksessa Andrew Calabrese \& Jean-Claude Burgelman (toim.): Communication, Citizenship, and Social Policy. Lanham: Rowman \& Littlefield, 65-76.

Raboy, Marc, Serge Proulx \& Peter Dahlgren (2003)

The Dilemma of Social Demand. Shaping Media Policy in New Civic Contexts. Gazette 65:4-5, 323-329.

Rose, Nikolas \& Miller, Peter (1992)

Political Power Beyond the State: Problematics of Government. British Journal of Sociology 43;2, 173-205.

Rose, Nikolas (1999)

Powers of Freedom. Reframing Political Thought. Cambridge University Press.

Sarikakis, Katherine (2004)

Powers in Media Policy. The Challenge of the European Parliament. Oxford: Peter Lang.

Sunstein, Cass (2003)

The Law of Group Polarization. Teoksessa Fishkin, James S. \& Laslett, Peter (toim.) Debating Deliberative Democracy.Oxford: Blackwell.

Syvertsen, Trine (2003)

Challenges to Public Television in the Era of Convergence and Commercialization. Television \& New Media $4: 2,155-175$

Van Cuilenburg, Jan (1998)

Diversity Revisited: Towards a Critical Rational Model of Media Diversity. Teoksessa Kees Brants, Joke Hermes \& Liesbet van Zoonen (toim.) The Media in Question. London: Sage, 38-49.

Van Cuilenburg, Jan \& Denis McQuail (2003)

Media Policy Paradigm Shifts. Towards a New Communications Policy Paradigm. European Journal of Communication 18:2, 181-207.

Van der Wurff, Richard (2004)

Supplying and Viewing Diversity. The Role of Competition and Viewer Choice in Dutch Broadcasting. European Journal of Communication 19(29): 215-237.

Van Loon, Ad (2000)

Freedom versus aceess rights in a European context. Teoksessa Marsden, Christopher (toim.): Regulating the Global Information Society. London: Routledge. 285-303.

Venturelli, Shalini (1998)

Liberalizing the European Public Sphere. Politics, Regulation, and the Public Sphere. Oxford: Clarendon Press.

Wiio, Juhani (2005)

Tosi-TV:n myötä edessä on television uudelleenmäärittelyn aika. Tiedotustutkimus 27:4-5, 123-128. 